\title{
ANALISIS PENGARUH SUMBER-SUMBER KEUNGGULAN BERSAING BIDANG PEMASARAN TERHADAP KINERJA PERUSAHAAN MANUFAKTUR DI INDONESIA
}

\author{
Nursya'bani Purnama \\ Hery Setiawan \\ Fakultas Ekonomi \\ Universitas Islam Indonesia
}

\begin{abstract}
Hasil-hasil riset terdahulu meyebutkan keunggulan bersaing bidang pemasaran atau kompetensi pemasaran mempunyai pengaruh positif terhadap kinerja perusahaan. Sejumlah studi bidang pemasaran telah mengarah pada penjelasan kinerja bisnis dan berusaha menghubungkan kompetensi bidang pemasaran dalam mempengaruhi kinerja perusahaan. Penelitian ini dilakukan pada perusahaan dalam industri manufaktur di Indonesia untuk menguji kembali konsep hubungan sumber keunggulan bersaing bidang pemasaran dengan hasil kinerja perusahaan. Tujuan lain penelitian ini adalah untuk memperoleh bukti empiris mengenai pengaruh kompetensi bidang pemasaran terhadap kinerja perusahaan yang diukur dengan pangsa pasar (market share) dan pertumbuhan pangsa pasar (market share growth) dan menguji serta menganalisis pengaruh sumber-sumber keunggulan bersaing bidang pemasaran terhadap kinerja perusahaan-perusahaan manufaktur di Indonesia.
\end{abstract}

PENDAHULUAN

Perkembangan dan perubahan lingkungan yang begitu cepat dan dramatis, termasuk perubahan selera konsumen, kemajuan teknologi serta perubahan sosial ekonomi, telah mengakibatkan timbulnya persaingan bisnis dalam berbagai industri yang begitu ketat. Perkembangan dan perubahan terjadi secara lintas geografis. Secara populer perkembangan tersebut dikenal dengan istilah globalisasi (Siagian, 1995). Kondisi yang demikian menuntut perusahaan untuk bisa menggali dan mengembangkan sumber-sumber keunggulan bersaing agar dapat bertahan hidup. Sumber keunggulan bersaing dapat ditemukan dari kemampuan manajemen dalam menggali kompetensi bidang-bidang fungsional perusahaan yaitu kompetensi bidang pemasaran, pengembangan dan desain produk serta produksi (Porter, 1994; Heene \& Sanches, 1997).

Kompetensi bidang fungsional merupakan pengetahuan nyata dan keterampilan yang secara khusus tercermin dalam keahlian, kemampuan dan kinerja pemasaran, inovasi, penggunaan teknologi dan produksi. Kompetensi yang dimiliki oleh perusahaan hendaknya tidak mudah ditiru oleh pesaing dan menopang tercapainya keunggulan kompetitif yang berkelanjutan (Heene \& Sanches, 1997). Keunggulan bersaing bukan merupakan ide baru, tetapi penekanaannya pada bidang pemasaran baru menjadi trend pada dekade 1980-an (Tjiptono, 1997). Sementara pandangan tradisional menempatkan pemasaran sebagai salah satu anggota tubuh perusahaan. 
Dalam era globalisasi dan liberalisasi perdagangan, hal itu perlu dikaji ulang atau diredefinisi. Pemasaran kini harus dijadikan sebagai jiwa, sehingga setiap orang dalam perusahaan adalah pemasar. Dengan demikian, pemasaran bukan hanya monopoli fungsi pemasaran, tetapi menjiwai setiap orang dalam mengambil keputusan.

Banyak riset para ahli yang telah membuktikan bahwa keahlian ataupun keterampilan superior (superior skills) akan menghasilkan superioritas kinerja (superior performance). Keterampilan superior merupakan kompetensi unik (distinctive competence) yang mendukung perusahaan untuk mencapai keunggulan posisional (positional advantage). Keunggulan posisional perusahaan dinyatakan dengan hasil-hasil kinerja (performance outcomes). Sedangkan indikator yang paling sering digunakan untuk mengevaluasi atau mengukur hasil-hasil kinerja adalah pangsa pasar (market share) dan profitabilitas (Szimansky, dkk, 1993). Beberapa riset di bidang pemasaran juga telah membuktikan bahwa kompetensi pemasaran mempunyai pengaruh positif terhadap hasil-hasil kinerja perusahaan. Jadi apabila kompetensi pemasaran meningkat maka hasil-hasil kinerja perusahaan juga akan meningkat, begitu juga sebaliknya. Penelitian ini mencoba menguji kembali konsep hubungan tersebut pada perusahaan-perusahaan manufaktur di Indonesia.

Untuk meningkatkan daya saing perusahaan, salah satu cara yang bisa ditempuh adalah dengan mengembangkan kapabilitas ataupun kompetensi perusahaan (Tambunan, 2001). Penelitian ini mencoba melihat pengaruh kompetensi bidang pemasaran terhadap keunggulan bersaing, terutama dilihat dari perbandingan relatif pangsa pasar dan pertumbuhan pangsa pasar. Diharapkan hasil penelitian ini dapat dipergunakan sebagai solusi alternatif perusahaan dalam menggali sumber-sumber keunggulan bersaing terutama di bidang pemasaran untuk bisa meningkatkan kinerja industri manufaktur di Indonesia.

\section{KAJIAN PUSTAKA}

\section{Konsep Keunggulan Bersaing (Competitive Advantage)}

Keunggulan bersaing berkaitan dengan cara bagaimana perusahaan memilih dan benar-benar dapat melaksanakan strategi generik ke dalam praktik (Porter, 1994). Semua bagian yang ada dalam organisasi, baik yang berupa sumber daya maupun aktifitas, dapat menjadi keunggulan bersaing melalui 3 alternatif strategi: cost leadership, differentiation, atau focus. Dengan memperkenalkan suatu alat yang dikenal sebagai analisis rantai nilai, manajemen dapat memisahkan aktifitas-aktifitas dasar yang dilakukan oleh perusahaan, mulai dari aktivitas desain, proses produksi, pemasaran sampai dengan jasa pelayanan setelah penjualan dan semua kegiatan 
pendukung mulai dari manajemen sumber daya manusia, infrastruktur, pembelian dan pengembangan teknologi (lihat gambar 1). Porter memberikan sebuah perspektif baru dan praktis tentang strategi bersaing dengan memperlihatkan bagaimana semua aktifitas dasar dan aktifitas pendukung ini dapat dipadukan sehingga membentuk sinergi yang pada gilirannya akan mendatangkan keunggulan bersaing.

Dengan menggunakan analisis rantai nilai ini, manajemen dapat melakukan aktivitas berikut:

- Memahami perilaku biaya

- Mengidentifikasi apa yang menciptakan nilai bagi pembeli

- Memilih strategi teknologi yang mencerminkan signifikansi teknologi perusahaan untuk keunggulan bersaing

- Memanajemeni hubungan strategik antar unit usaha yang ada, dan sebagainya.

\section{Gambar 1.}

Analisis Rantai Nilai Aktivitas Primer

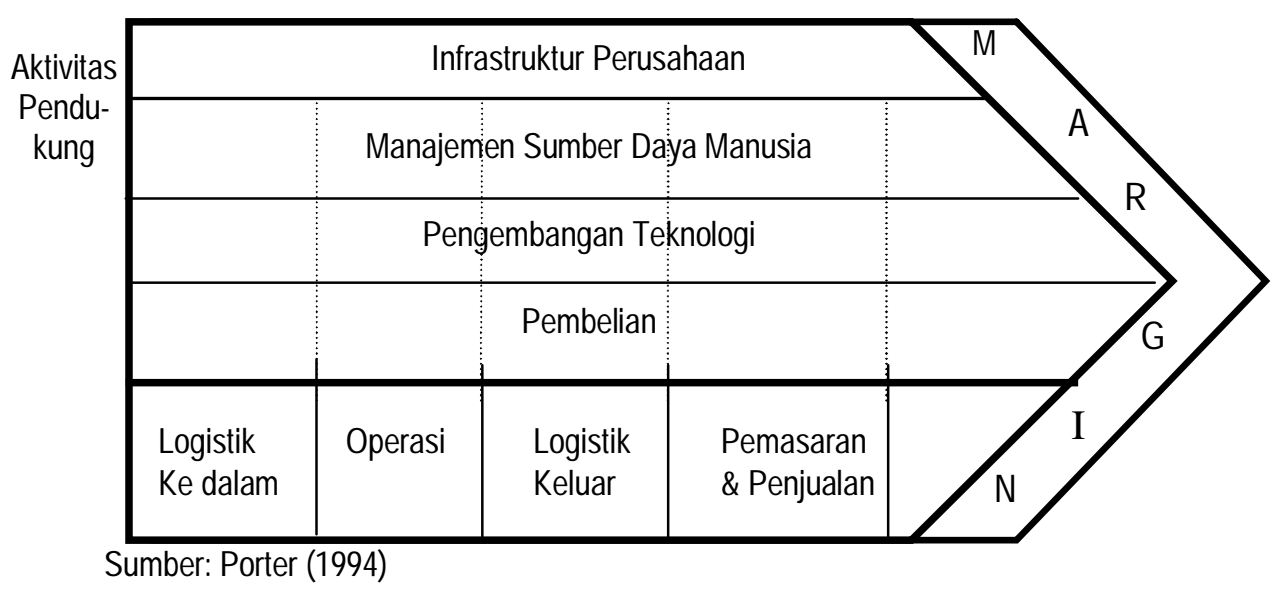

Cravens (1996) mengemukakan bahwa keunggulan bersaing seharusnya dipandang sebagai suatu proses dinamis bukan sekedar dilihat sebagai hasil akhir. Keunggulan bersaing memiliki tahapan proses seperti terlihat pada gambar 2 yang terdiri atas sumber keunggulan, keunggulan posisi dan prestasi hasil akhir serta investasi laba untuk mempertahankan keunggulan. 
Gambar 2. Elemen-Elemen Keunggulan Bersaing

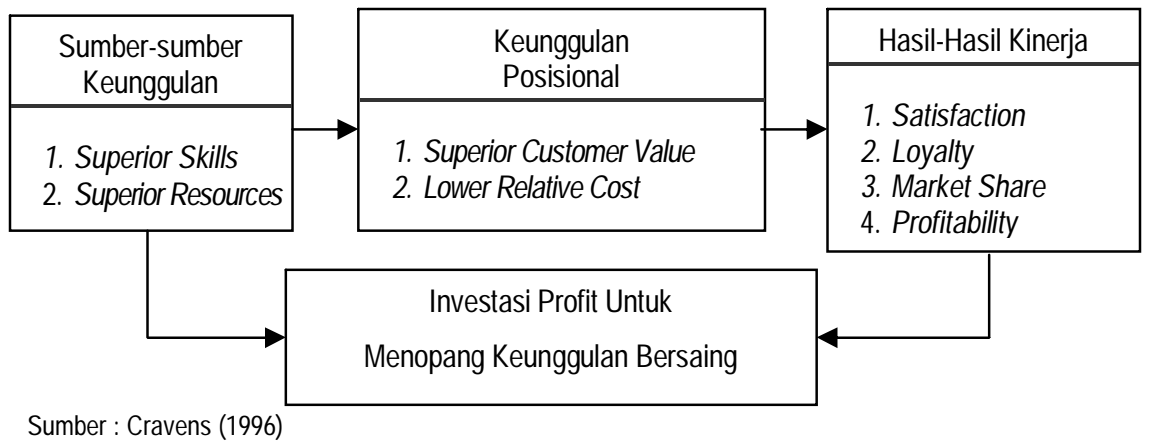

Analisis keunggulan bersaing menunjukkan perbedaan dan keunikannya di antara para pesaing. Sumber keunggulan bersaing itu adalah keterampilan, sumber daya dan pengendalian yang superior. Keterampilan yang superior memungkinkan organisasi untuk memilih dan melaksanakan strategi yang akan membedakan organisasi dari persaingan. Keterampilan mencakup kemampuan teknis, manajerial dan operasional. Sebagai contoh, pengetahuan tentang keinginan dan permintaan konsumen membantu perusahaan dalam menggunakan kemampuannya untuk memuaskan konsumen. Sementara itu, sumber daya yang superior memungkinkan pembentukan dimensi keunggulan. Contohnya, jaringan kerja distribusi yang kuat, kemampuan produksi, kekuatan pemasaran (wiraniaga yang berpengalaman), teknologi dan sumber daya alam. Pengendalian yang superior mencakup kemampuan memantau dan menganalisis proses dan hasil bisnis. Sebagai contoh, pengendalian biaya superior menghambat biaya dan pengenalan bidang dimana penilaian dan tindakan manajemen diperlukan. Sistem pengendalian juga memberikan kinerja patok duga (bench mark). Usaha-usaha pemantauan sebaiknya lebih dari sekedar operasional interen, tetapi juga meliputi para konsumen, pesaing dan jaringan kerja distribusi.

Keunggulan posisi merupakan hasil produksi dengan biaya rendah (cost leadership) atau diferensiasi yang memberikan keunggulan nilai bagi konsumen. Biaya yang lebih rendah memungkinkan perusahaan memberikan nilai yang superior dengan pemberian harga yang lebih rendah dari para pesaing untuk produk yang sama. Perbedaan penampilan produk yang sesuai dengan preferensi pembeli menghasilkan manfaat unik yang dapat menutupi harga tinggi. Faktor penting dalam mencari keunggulan adalah bagaimana mengambil keputusan bersaing.

Pada saat keterampilan organisasi, sumber daya, dan pengendalian digunakan untuk meperoleh nilai dan atau efisiensi biaya, keunggulan 
posisi telah menuju pada prestasi dari hasil akhir (kepuasan konsumen, kesetiaan terhadap merek, pangsa pasar, dan kemampuan mendapatkan laba) seperti yang ditunjukkan pada Gambar 2. Keunggulan bersaing merupakan sasaran yang selalu berubah. Karenanya, manajemen harus menggunakan sebagian labanya untuk mempertahankan keunggulan tersebut.

Bagi produsen yang ingin menikmati keunggulan bersaing di pasar, perbedaan antara produknya dan produk pesaing harus dapat dirasakan di pasaran. Mereka harus dapat merefleksikan pada beberapa produk/atribut yang akan disampaikan, yang merupakan kriteria pokok pembelian (key buying criterion) pasar. Kesenjangan kapasitas (a capabelity gap) adalah perbedaan antara posisi perusahaan dan pesaing terkuat untuk kriteria pembelian. Keunggulan bersaing terjadi pada saat kemampuan perusahaan melebihi pesaing terkuat untuk kriteria pembelian yang penting bagi para pembeli. Keunggulan bersaing diperoleh dengan mencari aspek-aspek diferensiasi yang akan dinilai sebagai nilai superior oleh konsumen sasaran dan yang tidak mudah diduplikasikan oleh pesaingnya.

Para pesaing selalu berusaha untuk mengurangi atau menghilangkan kesenjangan kapasitas tersebut. Keunggulan dipertahankan dengan berjuang sekuat tenaga untuk melakukan perbaikan secara terus menerus terhadap nilai yang diberikan pada para pembeli dan atau mengurangi biaya dalam menyediakan produk atau jasa. Produk baru yang sesuai dengan keinginan konsumen dan lebih baik ketimbang produk yang sudah ada juga dapat menciptakan keunggulan. (Cravens, 1996)

Untuk bisa mencapai keunggulan bersaing berkelanjutan perlu diciptakan hambatan sehingga sulit bagi pesaing untuk melakukan imitasi. Hambatan imitasi lambat laun akan terkikis dengan bertambahnya pesaing dan meningkatnya persaingan, sehingga perusahaan dituntut terus menerus memperbaiki kompetensinya untuk mempertahankan keunggulan bersaing yang dimilikinya. Jadi penciptaan keunggulan bersaing merupakan hasil umpan balik jangka panjang atau suatu proses siklis (gambar 2). Proses siklis atau determinism sequential tersebut berada dalam kondisi lingkungan yang kompleks, penuh ketidak pastian, penyimpangan-penyimpangan umpan balik dan kekakuan struktural.

\section{Konsep Strategi Pemasaran}

Setiap fungsi manajemen memberikan kontribusi tertentu pada saat penyusunan strategi pada level yang berbeda. Pemasaran merupakan fungsi yang memiliki kontak paling besar dengan lingkungan eksternal, padahal perusahaan hanya memiliki kendali yang terbatas terhadap lingkungan eksternal. Oleh karena itu pemasaran memainkan peranan penting dalam pengembangan strategi (Tijptono, 1997). 
Dalam peranan strategisnya, pemasaran mencakup setiap usaha untuk mencapai kesesuaian antara perusahaan dengan lingkungannya dalam rangka mencari pemecahan atas dua masalah pokok. Pertama, bisnis apa yang digeluti perusahaan pada saat ini dan jenis bisnis apa yang dapat dimasuki di masa mendatang. Kedua, bagaimana bisnis yang telah dipilih tersebut dapat dijalankan dengan sukses dalam lingkungan yang kompetitif atas dasar perspektif produk, harga, promosi dan distribusi (bauran pemasaran) untuk melayani pasar sasaran.

Strategi pemasaran merupakan pernyataan (baik secara implisit maupun eksplisit) mengenai bagaimana suatu merek atau lini produk mencapai tujuannya. Selain itu strategi pemasaran juga didefinisikan sebagai alat fundamental yang direncanakan untuk mencapai tujuan perusahaan dengan mengembangkan keunggulan bersaing yang berkesinambungan melalui pasar yang dimasuki dan program pemasaran yang digunakan untuk melayani pasar sasaran tersebut. Pada dasarnya strategi pemasaran memberikan arah dalam kaitannya dengan variabel-variabel seperti segmentasi pasar, identifikasi pasar sasaran, positioning, elemen bauran pemasaran dan biaya bauran pemasaran. Strategi pemasaran merupakan bagian integral dari srategi bisnis yang memberikan arah pada semua fungsi manajemen suatu organisasi.

Strategi pemasaran terdiri atas lima elemen yang saling berkait. Kelima elemen tersebut adalah:

1. Pemilihan pasar, yaitu memilih pasar yang akan dilayani dimulai dengan melakukan segmentasi pasar dan kemudian memilih pasar sasaran yang paling memungkinkan untuk dilayani oleh perusahaan.

2. Perencanaan produk, meliputi pembentukan lini produk dan desain penawaran individual pada masing-masing lini.

3. Penetapan harga, yaitu menentukan harga yang dapat mencerminkan nilai kuantitatif dari produk kepada pelanggan.

4. Sistem distribusi, yaitu saluran perdagangan grosir dan eceran yang dilalui produk hingga mencapai konsumen akhir yang membeli dan menggunakannya.

5. Komunikasi pemasaran (promosi), yang meliputi periklanan, personal selling, promosi penjualan, direct markting dan public relations.

\section{Kompetensi Bidang Pemasaran Perusahaan}

Kompetensi perusahaan pada prinsipnya meliputi kapabilitas yang berhubungan dengan teknologi dan keahlian yang diperoleh melalui organizational learning atau collective learning (Prahalad, dkk, 1994). Kompetensi mendukung aliran dan penggunaan pengetahuan baru yang didapat dalam perusahaan. 
Gambar 3.

Model Perumusan Strategi Pemasaran

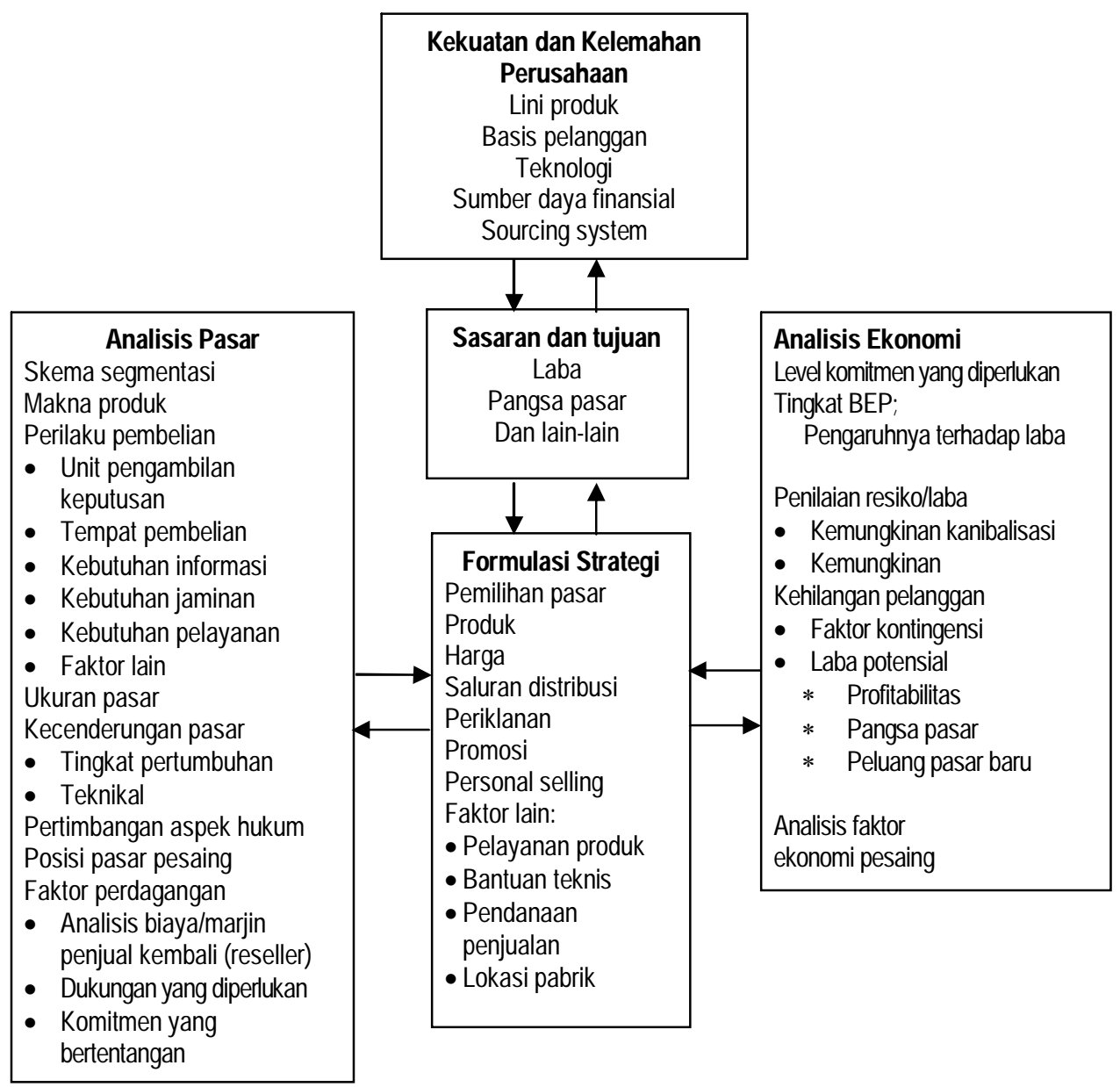

Kompetensi mengarahkan pola-pola diversifikasi dan cara perusahaan masuk ke pasar (market entry). Kompetensi khusus merupakan keunggulan bersaing yang dimiliki atau dilakukan perusahaan yang memberinya kekuatan untuk menghadapi pesaing (Tjiptono, 1997).

Kompetensi pemasaran merupakan kemampuan dan tingkat kinerja bidang pemasaran yang mendukung tercapainya tujuan strategik perusahaan. Besarnya kompetensi pemasaran dihitung dengan mengetahui nilai total kinerja faktor-faktor keunggulan bersaing dikalikan dengan tingkat pentingnya faktor-faktor tersebut dan besarnya persentase tanggung jawab bidang pemasaran. Rumus yang digunakan oleh Vickery, dkk. (1994) adalah sebagai berikut: 


\section{Kompetensi Pemasaran $=\Sigma[($ M\% Responsibility $) \times$ (Importance) $\times$ (Performance)}

Pelayanan pelanggan, harga kompetitif, luasnya cakupan distribusi, citra merek, promosi dan reputasi perusahaan adalah metode-metode bersaing untuk memperoleh, menopang dan memperbaiki keunggulan bersaing (Dess \& Davis, 1984). Hampir sependapat dengan Dess dan Davis, menurut Varadarajan (1985) strategi pemasaran serta elemen-elemen marketing mix yang meliputi luasnya lini produk, pelayanan pelanggan, luasnya cakupan distribusi, harga bersaing, penguasaan penjualan personal, periklanan, promosi dan distribusi dianggap sebagai sumber-sumber keunggulan bersaing.

Hasil studi literatur tentang sumber keunggulan bersaing, fungsi pemasaran mempunyai tanggung jawab yang besar terhadap 12 prioritas kompetitif (dikembangkan dari berbagai literatur dan penelitian terdahulu di Indonesia). Kedua belas faktor keunggulan kompetitif yang merupakan sumber keunggulan bersaing bidang pemasaran tersebut dapat dilihat pada tabel 1.

Tabel 1.

Sumber-sumber Keunggulan Bersaing Bidang Pemasaran

\begin{tabular}{|l|l|}
\hline No. & \multicolumn{1}{|c|}{$\begin{array}{c}\text { Sumber-sumber Keunggulan Bersaing } \\
\text { Bidang Pemasaran }\end{array}$} \\
\hline 1. & Citra merek (brand image) \\
2. & Promosi periklanan \\
3. & Identifikasi pasar sasaran \\
4. & Kemampuan memenuhi tuntutan pasar sasaran (target market) \\
5. & Penetapan harga \\
6. & Pelayanan pelanggan sebelum dan setelah penjualan \\
7. & Luasnya lini produk \\
8. & Luasnya cakupan distribusi \\
9. & Distribusi biaya rendah \\
10. & Distribusi selektif \\
11. & Penguasaan penjualan secara personal \\
12. & Reputasi perusahaan \\
\hline
\end{tabular}

Merek dapat berupa nama, istilah atau lambang yang dapat mengidentifisikan sebuah perusahaan. Merek sebaiknya dibuat secara unik, mudah diingat dan dibedakan dengan yang lain. Merek yang sudah mempunyai kekuatan hukum dapat melindungi perusahaan dari upaya peniruan pesaing, disamping membuat proses pembelian konsumen menjadi lebih mudah dan efisien. Berbagai strategi merek dapat dipilih oleh 
perusahaan, apakah setiap produk akan diberikan merek tersendiri atau sebaliknya semua produk yang dikeluarkan akan diberi merek yang sama.

Promosi merupakan salah satu program bauran pemasaran yang pada hakekatnya merupakan suatu bentuk komunikasi dimana sendernya adalah pihak pemasar dan receivernya adalah pihak stakeholder, terutama pasar. Ada beberapa alat yang bisa digunakan untuk promosi, seperti periklanan, penjualan perorangan, promosi perdagangan, publikasi dan pemasaran langsung (Kotler, 2000). Kelima alat tersebut sering dikenal dengan istilah bauran promosi.

Bauran promosi ini harus dibuat secara tepat dengan mempertimbangkan jenis produknya (termasuk produk industri atau produk untuk konsumen individual), tahap daur hidup produk (apakah produk berada pada tahap perkenalan, pertumbuhan, kedewasaan atau penurunan), tahap kesiapan pembeli (pembeli belum kenal sehingga perlu dibangun kesadarannya terhadap keberadaan produk atau pembeli sudah sampai tahap perlu diyakinkan untuk membeli) dan sebagainya.

Identifikasi pasar sasaran dimulai dengan proses pembagian pasar yang sering dikenal dengan istilah segmentasi. Segmentasi berusaha mengelompokkan konsumen ke dalam segmen-segmen, dimana masing-masing segmen diharapkan memiliki perilaku dan tanggapan yang sama terhadap bauran pemasaran tertentu. Segmentasi bisa dilakukan berdasarkan faktor geografis, demografis, psikologis ataupun perilaku. Setelah dihasilkan beberapa segmen pasar, barulah proses pemilihan target segmen pasar sasaran bisa dilakukan. Berbagai strategi pencakupan segmen pasar yang akan dilayani bisa dipilih, mulai dari pencakupan segmen tunggal, pencakupan beberapa segmen secara selektif ataupun pencakupan segmen pasar secara keseluruhan. Dasar pertimbangan (seperti besarnya segmen, tingkat pertumbuhan segmen, tingkat profitabilitas segmen, tingkat persaingan dalam setiap segmen dan sebagainya) harus diperhatikan disamping sumberdaya dan kemampuan perusahaan itu sendiri didalam memenuhi tuntutan segmen pasar yang dijadikan sasaran.

Produk merupakan segala sesuatu yang dapat memuaskan kebutuhan dan keinginan konsumen. Segala sesuatu yang dimaksud disini dapat berupa barang yang kasat mata (seperti mobil, komputer, sepatu, baju, meja dan sebagainya) maupun sesuatu yang tidak bisa dilihat atau diraba tetapi bisa dirasakan manfaatnya (sering disebut dengan jasa). Bahkan tempat, organisasi dan orangpun bisa disebut produk selama dapat memenuhi kebutuhan dan keinginan kita (Kotler, 2000).

Produk dapat diuraikan kedalam lima tingkatan. Tingkat pertama disebut sebagai produk inti, yang menunjukkan manfaat atau jasa yang ditawarkan oleh produk tersebut. Sebagai contoh jika produknya berupa mobil maka produk intinya adalah alat transportasi. Jika produknya berupa hotel 
maka jasa yang ditawarkan adalah sebagai tempat beristirahat. Tingkatan kedua disebut sebagai produk dasar, yang menunjukkkan ciri dasar dari produk. Sebagai contoh, ciri dasar dari hotel adalah bangunan yang memiliki banyak kamar, dimana tiap kamar ada tempat tidurnya, almari, meja, kamar mandi dan sebagainya. Pada tingkatan kedua ini antara produk satu perusahaan dengan perusahaan lain belum begitu dapat dibedakan karena masih belum diberi merek, belum dipikirkan tingkatan kualitasnya, kemasannya dan sebagainya. Tingkatan ketiga disebut sebagai produk yang diharapkan. Pemberian merek, tingkatan kualitas, masalah kemasan dan model (style) sudah harus dipertimbangkan dalam tingkatan ketiga ini. Penggabungan tingkatan kedua dan ketiga ini sering disebut sebagai produk aktual. Tingkatan keempat berkaitan dengan upaya membuat konsumen senang dengan produk yang dibeli (lebih dari sekedar puas). Pemberian garansi, pelayanan pelanggan sebelum dan sesudah penjualan, jasa pengantaran produk sampai tempat pembeli, jasa pemasangan dan sebagainya sudah dipertimbangkan dalam tingkatan keempat ini. Misal produknya adalah sebuah perguruan tinggi, maka taman yang teduh dan tenang untuk membaca atau belajar pada jam istirahat, tempat parkir yang luas dan aman, pusat kesehatan yang lengkap fasilitasnya merupakan halhal yang dapat membuat mahasiswa semakin senang. Sebuah perusahaan yang membuat lini produk yang luas juga akan membuat konsumen lebih senang. Tingkatan kelima berkaitan dengan upaya pengembangan produk untuk masa yang akan datang. Bagian research and development perusahaan harus senantiasa melakukan penelitian untuk melihat kemungkinan pengembangan produk yang akan datang (misalnya agar memiliki siklus kehidupan yang panjang dan sebagainya).

Penetapan harga harus mempertimbangkan beberapa faktor seperti tujuan pemasaran, kesesuaian dengan bauran pemasaran yang lain, biaya produksi, harga pesaing, kondisi perekonomian dan sebagainya. Jika tujuan pemasaran yang ditetapkan adalah menjadi pemimpin pasar dalam hal pangsa pasar maka harga akan ditetapkan rendah, sebaliknya jika tujuan pemasaran adalah menjadi pemimpin pasar dalam hal kualitas maka untuk menutup biaya produksi harga akan ditetapkan tinggi. Selanjutnya, bauran pemasaran yang lain (diluar harga) juga harus mendukung, misal harga ditetapkan tinggi maka promosinya juga harus di media yang biasa dibaca kalangan berpendapatan tinggi, saluran distribusinya eksklusif dan desain produknya juga harus berkualitas.

Saluran distribusi merupakan sekelompok perusahaan atau perorangan yang mengambil alih hak atau membantu proses pengalihan hak selama perpindahan produk dari produsen ke konsumen. Saluran distribusi bisa terdiri dari pedagang besar, agen maupun pedagang eceran. Dengan adanya saluran distribusi ini diharapkan proses penyebaran produk dari 
produsen ke konsumen akan lebih efektif dan efisien. Perusahaan harus mendesain dan mengelola saluran distribusi secara tepat.

Mendesain saluran distribusi berkaitan dengan keputusankeputusan seperti apakah akan menggunakan saluran distribusi atau tidak (zero level marketing), kalau memakai saluran distribusi perlu panjang (mungkin three level channel marketing) atau pendek (one level channel marketing), tipe saluran distribusi (agen atau wiraniaga) dan jumlahnya (intensif, selektif atau eksklusif). Sementara mengelola saluran distribusi berkaitan dengan keputusan tentang siapa saja yang akan direkrut sebagai anggota saluran (yang sudah berpengalaman, yang mudah diajak kerjasama dan sebagainya), bagaimana memotivasi dan mengevaluasi anggota yang sudah di rekrut.

Sumber keunggulan bersaing nomor satu sampai dengan sebelas akan sangat mempengaruhi reputasi perusahaan (sebagai sumber keunggulan bersaing yang keduabelas). Menurut beberapa pakar manajemen, reputasi perusahaan yang baik pada gilirannya diharapkan dapat meningkatkan profitabilitas perusahaan yang salah satunya bisa melalui perluasan pangsa pasar.

\section{Kinerja Perusahaan}

Kinerja perusahaan adalah tingkat pencapaian prestasi perusahaan yang diukur dalam bentuk hasil-hasil kerja atau performance outcome (Rue \& Byard, 1997). Berdasar hasil penelitian Szimansky, dkk. (1993) indikator pengukuran kinerja dan keunggulan bersaing yang paling sering digunakan adalah market share dan profitabilitas. Dalam penelitian ini peneliti hanya menggunakan pangsa pasar (market share) sebagai indikator pengukuran kinerja perusahaan yang kemudian dilengkapi dengan pertumbuhan pangsa pasar (market share growth).

Market share adalah pengukuran kinerja pemasaran atau kinerja operasional yang dapat membedakan antara pemenang dan pecundang. Volume penjualan perusahaan tidak mengungkapkan sebaik apa kinerja perusahaan dibanding pesaingnya. Jika market share perusahaan meningkat berarti perusahaan dapat mengungguli pesaingnya, jika maket share perusahaan menurun, dapat dikatakan perusahaan kalah dari pesaingnya. Yang dimaksud market share disini adalah pangsa pasar relatif, yaitu total penjualan perusahaan yang dinyatakan sebagai persentase penjualan terhadap major competitor. Pengukuran dengan pangsa pasar keseluruhan ini banyak digunakan karena hanya membutuhkan informasi tentang penjualan total (Kotler, 1997). Penelitian ini juga menggunakan pengukuran pangsa pasar relatif dengan menanyakan perbandingan pangsa pasar responden dengan pesaing utama mereka. 


\section{TINJAUAN PENELITIAN TERDAHULU}

Sejumlah studi bidang pemasaran telah mengarah pada penjelasan kinerja bisnis dan berusaha menghubungkan kompetensi bidang pemasaran dalam mempengaruhi kinerja perusahaan.

Salah satu studi bidang pemasaran yang terkenal adalah program PIMS (Profit Impact of Marketing Strategy) yang dilakukan sekitar tahun 1970-an. Program PIMS merupakan suatu studi yang menganalisis faktorfaktor yang menentukan kinerja pada 2000 unit bisnis dari 200 perusahaan di Amerika. Studi ini menghasilkan penemuan riset yang komprehensif tentang penentu-penentu kinerja (misalnya pengaruh periklanan dan kualitas produk pada ROI atau market share). Craig (1982) menggunakan data PIMS untuk meneliti pengaruh marketing mix dan variabel-variabel struktur industri terhadap kinerja perusahaan. Hasil studi Craig menunjukkan bahwa kualitas produk secara signifikan mempengaruhi market share dan ROI. Hasil studi Philliph Kotler, dkk (1983) yang menguji hubungan kualitas produk dan posisi biaya dengan kinerja perusahaan mendukung temuan Craig (1982). Hasil studi ini secara kuat mengindikasikan bahwa kualitas produk mempengaruhi kinerja bisnis perusahaan.

Tahun 1998 dilakukan penelitian oleh Lena Ellitan tentang pengaruh sumber-sumber keunggulan kompetitif terhadap kinerja perusahaan pada sekitar 400 perusahaan yang terdaftar dalam directory Top Companies and Big Group in Indonesia. Penelitian yang mencoba menghubungkan pengaruh bidang fungsional perusahaan (bidang pemasaran, inovasi dan produksi) ini menunjukkan adanya hubungan positif antara kompetensi bidang fungsional (pemasaran dan produksi) dengan hasil kinerja perusahaan.

\section{METODOLOGI PENELITIAN}

\section{Populasi dan Sampel Penelitian}

Populasi dalam penelitian ini termasuk dalam populasi infinit, karena jumlah perusahaan yang berada dalam wilayah populasi tidak diketahui secara tepat atau secara pasti. Teknik pengambilan sampel menggunakan teknik non probability sampling (non random sampling), sampel diambil secara purposive sampling dari industri manufaktur yang sahamnya terdaftar di Bursa Efek Jakarta (BEJ) selama tahun 2000. Responden yang dipilih untuk mengisi kuesioner adalah manajer pemasaran dengan harapan mereka lebih mengetahui praktik dan kinerja bidang pemasaran di perusahaan mereka.

\section{Pengukuran Variabel Penelitian}

Untuk mengukur variabel-variabel dalam penelitian ini digunakan instrumen yang dikembangkan oleh Vickery, dkk. (1994) dan telah diadopsi 
dalam penelitian terkait sebelumnya di Indonesia, yaitu oleh Lena Ellitan pada tahun 1998.

\section{a. Variabel bebas}

Variabel bebas dalam penelitian ini adalah kompetensi bidang pemasaran. Yang dimaksud kompetensi pemasaran disini adalah kemampuan dan tingkat kinerja bidang pemasaran yang mendukung tercapainya tujuan strategik perusahaan. Variabel kompetensi pemasaran ini diukur dengan pertanyaan-pertanyaan yang berkaitan dengan 12 sumber keunggulan bersaing bidang pemasaran sebagai berikut :

1. Citra merek (brand image)

2. Promosi periklanan

3. Identifikasi pasar sasaran

4. Kemampuan memenuhi tuntutan pasar sasaran (target market)

5. Penetapan harga

6. Pelayanan pelanggan sebelum dan setelah penjualan

7. Luasnya lini produk

8. Luasnya cakupan distribusi

9. Distribusi biaya rendah

10. Distribusi selektif

11. Penguasaan penjualan secara personal

12. Reputasi perusahaan

Besarnya kompetensi pemasaran dihitung dengan mengetahui nilai total dari kinerja sumber-sumber keunggulan kompetitif dikalikan dengan tingkat pentingnya sumber-sumber tersebut dan besarnya persentase tanggung jawab bidang pemasaran. Rumus yang digunakan oleh Vickery, dkk. (1994) yaitu :

\section{M.Comp $=\Sigma[($ M\% Responsibility) $\times$ (Importance) $\times$ (Performance) $]$}

M\% menunjukkan persentase tanggung jawab fungsi pemasaran terhadap masing-masing sumber keunggulan. Alternatifnya antara 1 sampai dengan $100 \%$, tergantung pendapat responden tentang seberapa besar tanggung jawab fungsi pemasaran terhadap masing-masing sumber keunggulan. Semakin kecil persentase berarti sumber keunggulan bersaing tersebut semakin menjadi tanggung jawab fungsi lain yang ada dalam perusahaan.

Kinerja sumber-sumber keunggulan bersaing diukur dengan menggunakan skala Likert tujuh poin (seven poin scale) dengan nilai terendah 1 yang berarti kinerjanya sangat jelek dan nilai tertinggi 7 yang berarti kinerjanya sangat baik. Demikian juga dengan tingkat pentingnya sumber-sumber keunggulan bersaing diukur dengan menggunakan skala Likert tujuh poin (seven poin scale) dengan nilai terendah 1 yang berarti 
kinerjanya sangat tidak penting dan nilai tertinggi 7 yang berarti kinerjanya sangat penting.

\section{b. Variabel Terikat}

Variabel terikat dalam penelitian ini adalah hasil-hasil kinerja perusahaan yang dievaluasi berdasar dimensi: pangsa pasar (market share) dan pertumbuhan pangsa pasar (market share growth). Hasil-hasil kinerja (performance outcomes) adalah bentuk ukuran tingkat pencapaian prestasi perusahaan. Variabel-variabel ini diukur secara subyektif. Dalam pengukuran subyektif responden diminta menilai masing-masing dimensi ukuran kinerja secara relatif terhadap kompeti-tornya untuk menilai keunggulan posisional perusahaan atas pesaingnya.

Pengukuran kinerja diatas dinilai dengan menggunakan skala Likert tujuh poin (sevent poin scale) dengan nilai terendah 1 (the worst in the industry) artinya kinerjanya terjelek diantara pesaingpesaingnya dan nilai tertinggi 7 (the best in the industry) yang artinya kinerjanya paling baik diantara pesaing-pesaingnya.

Market share yang dimaksud dalam penelitian ini adalah pangsa pasar keseluruhan. Pangsa pasar keseluruhan yaitu total penjualan perusahaan yang dinyatakan sebagai persentase penjualan pasar keseluruhan. Pertumbuhan market share adalah persentase perubahan market share selama tiga tahun terakhir.

\section{Uji Reliabilitas dan Validitas}

Instrumen yang digunakan dalam penelitian ini tidak diuji reliabilitas dan validitasnya karena dalam menghitung kompetensi bidang pemasaran terdapat pertanyaan-pertanyaan yang bersifat terbuka, yaitu dalam memberikan penilaian besarnya persentase tanggung jawab bidang pemasaran terhadap faktor-faktor keunggulan kompetitif (dinyatakan dalam \%).

\section{Metode Pengumpulan Data}

Data penelitian mengenai kompetensi pemasaran dan hasil-hasil kinerja perusahaan dikumpulkan dengan penyebaran kuesioner melalui surat (mailed questionnareis) yang ditujukan pada Manajer Pemasaran (marketing manager) sebagai responden.

Menurut Indonesian Capital Market Directory (2000), perusahaanperusahaan manufaktur di Indonesia yang terdaftar dalam Bursa Efek Jakarta diklasifikasikan kedalam 21 kelompok sebagai berikut:

1. Makanan dan Minuman (Food and Beverages)

2. Produk Tembakau (Tobacco Product)

3. Tekstil (Textile)

4. Pakaian dan Produk Tekstil lain (Apparel and Other Textile Product)

5. Kayu dan Produk Kayu (Lumber and Wood Products) 
6. Kertas dan Produk Gabungannya (Paper and Allied Products)

7. Produk Kimia dan Gabungannya (Chemical and Allied Products)

8. Bahan Perekat (Adhesive )

9. Produk Plastik dan Kaca (Plastic and Glass Products)

10. Semen (Cement)

11. Produk Logam (Metal Products)

12. Produk yang Terbuat dari Logam (Fabricated Metal Products)

13. Produk dari Batu, Tanah Liat dan Kaca (Stone, Clay, Glass and Concrete Products)

14. Mesin-Mesin (Machinery)

15. Kabel (Cable)

16. Peralatan Kantor dan Elektronik (Electronic and Office Equipment)

17. Produk Otomotif dan Gabungannya (Automotive and Allied Products)

18. Peralatan Fotografi (Photographic Equipment)

19. Produk Farmasi (Pharmaceutical)

20. Barang- Barang Konsumen (Consumer Goods)

21. Perusahaan-Perusahaan Manufaktur yang Lain (Other Manufacturing).

\section{Metode Analisis Data}

Data dalam, penelitian ini dianalisis menggunakan analisis regresi. Analisis regresi yang menyangkut sebuah variabel independen dan sebuah variabel dependen dinamakan analisis regresi sederhana (Nasir, 1988). Model umum persamaan regresi sederhana menurut Nasir (1988) dan Dajan (1986) adalah sebagai berikut:

dimana:

$$
Y_{i}=\beta_{0}+\beta_{i} X_{i}+e_{i}
$$

$Y_{i}=$ variabel dependen/terikat

$X_{i}=$ variabel independen/bebas

$\beta_{0}=$ konstanta

$\beta_{\mathrm{i}}=$ koefisien regresi

$\mathrm{e}_{\mathrm{i}}=$ disturbance error

Untuk menguji pengaruh sumber-sumber keunggulan bidang pemasaran (kompetensi pemasaran) terhadap hasil kinerja perusahaan, data yang diperoleh dalam penelitian ini akan diuji dengan model regresi sederhana. Model regresi yang dimaksud adalah sebagai berikut :

dimana :

$$
\begin{aligned}
& Y_{1}=\beta_{0}+\beta_{1} X_{1}+e_{1} \\
& Y_{2}=\beta_{0}+\beta_{2} X_{1}+e_{2}
\end{aligned}
$$


$Y_{1}$ adalah market share

$Y_{2}$ adalah market share growth

$\mathrm{X}_{1}$ adalah kompetensi pemasaran (marketing competence)

$\beta_{0}$ adalah konstanta

$\beta_{i}$ adalah koefisien regresi

e adalah disturbance error

\section{HASIL PENELITIAN DAN PEMBAHASAN}

Hasil akhir pengumpulan kuesioner dari September sampai dengan akhir Desember 2001 dapat dilaporkan bahwa dari total kuesioner yang dikirimkan yaitu sebanyak 147, 40 kuesioner kembali pada penulis. Dengan demikian respon rate penelitian ini sekitar 27\%. Dari semua kuesioner yang kembali, 4 tidak diolah lebih lanjut karena tidak lengkap jawabannya. Jadwal penyebaran kuesioner memang bersamaan dengan sibuk-sibuknya perusahaan menjelang pembuatan laporan tutup buku akhir tahun, sehingga meskipun penulis sudah berusaha semaksimal mungkin data yang terkumpul dan dapat diolah dalam penelitian ini hanya sebanyak 36 perusahaan.

\section{Statistik Deskriptif}

a. Tanggung Jawab (Responsibility) Bidang Pemasaran Perusahaan

Tabel 2 menggambarkan besarnya tanggung jawab fungsi pemasaran terhadap masing-masing sumber keunggulan bersaing di bidang pemasaran. Dari tabel 2, kita dapat melihat bahwa citra merek dan reputasi perusahaan merupakan sumber keunggulan bersaing yang menjadi tanggung jawab terbesar fungsi pemasaran (sekitar $80 \%$ ). Fungsi-fungsi lain yang ada dalam perusahaan, seperti produksi/operasional, keuangan, sumber daya manusia dan sebagainya dituntut juga untuk bertanggung jawab sebesar kurang lebih $20 \%$ terhadap kedua sumber keunggulan bersaing ini.

Identifikasi pasar sasaran menjadi tanggung jawab terbesar berikutnya. Sekitar 75\% sumber keunggulan bersaing ini diakui oleh responden menjadi tanggung jawab fungsi pemasaran, 25\% sisanya menjadi tanggung jawab fungsi-fungsi lain. Kemampuan memenuhi tuntutan pasar sasaran (tanggung jawab terbesar keempat, sebesar 66\%) dan promosi/periklanan (tanggung jawab terbesar kelima, sebesar 65\%) menempati urutan berikutnya. Fungsi-fungsi lain yang ada dalam perusahaan semakin dituntut tanggung jawabnya terhadap dua sumber keunggulan bersaing ini (sebesar kurang lebih 3\%) 
Tabel 2.

Rerata Persentase dan Peringkat Tanggung Jawab Fungsi Pemasaran terhadap Sumber-sumber Keunggulan Bersaing Bidang Pemasaran

\begin{tabular}{|r|l|c|c|}
\hline No & \multicolumn{1}{|c|}{ Prioritas Keunggulan Bersaing Bidang Pemasaran } & Persentase & $\begin{array}{c}\text { Peringkat } \\
\text { (Rank) }\end{array}$ \\
\hline 1. & Citra merek (brand image) & 80,5556 & 2 \\
\hline 2. & Promosi periklanan & 65,8333 & 5 \\
\hline 3. & Identifikasi pasar sasaran & 75,8333 & 3 \\
\hline 4. & Kemampuan memenuhi tuntutan pasar sasaran (target market) & 66,2500 & 4 \\
\hline 5. & Penetapan harga & 45,8333 & 12 \\
\hline 6. & Pelayanan pelanggan sebelum dan setelah penjualan & 49,1667 & 11 \\
\hline 7. & Luasnya lini produk & 54,3056 & 8 \\
\hline 8. & Luasnya cakupan distribusi & 61,8056 & 6 \\
\hline 9. & Distribusi biaya rendah & 49,4444 & 10 \\
\hline 10. & Distribusi selektif & 55,6944 & 7 \\
\hline 11. & Penguasaan penjualan secara personal & 51,9444 & 9 \\
\hline 12. & Reputasi perusahaan & 80,6944 & 1 \\
\hline
\end{tabular}

Fungsi pemasaran dituntut tanggung jawabnya sebesar kurang lebih 50 sampai dengan $60 \%$ untuk sumber-sumber keunggulan seperti penguasaan penjualan secara personal, luasnya lini produk, distribusi selektif dan luasnya cakupan distribusi. Ini berarti kurang lebih 40 sampai dengan 50\% tanggung jawab sumber-sumber keunggulan ini menjadi tanggung jawab fungsi-fungsi lain.

Sementara itu, penetapan harga, pelayanan pelanggan sebelum dan setelah penjualan, serta distribusi biaya rendah merupakan sumber keunggulan bersaing yang menjadi tanggung jawab fungsi pemasaran terkecil (kurang dari 50\%). Ini berarti, fungsi diluar pemasaran yang ada di perusahaan dituntut juga tanggung jawabnya dalam sumber-sumber keunggulan ini lebih dari $50 \%$.

b. Tingkat Pentingnya (Importance) Sumber-Sumber Keunggulan Bersaing Bidang Pemasaran

Rerata dan peringkat pentingnya (importance) sumber-sumber keunggulan bersaing bidang pemasaran ditunjukkan dalam tabel 3. Dari tabel 3 ini kita dapat melihat bahwa citra merek dan reputasi perusahaan dianggap sebagai sumber keunggulan bersaing yang paling penting, dilanjutkan dengan kemampuan memenuhi tuntutan pasar sasaran dan identifikasi pasar sasaran. Jika dikaitkan dengan tabel sebelumnya (Tabel 2, Rerata Persentase dan Peringkat Tanggung Jawab Fungsi Pemasaran Terhadap Sumber Keunggulan Bersaing Bidang Pemasaran) kita dapat menggaris 
bawahi bahwa sumber-sumber keunggulan bidang pemasaran yang dianggap paling penting ternyata memang menjadi tanggung jawab utama fungsi pemasaran (persentase tanggung jawabnya besar).

Tabel 3.

Rerata dan Peringkat Skor Pentingnya (Importance) Sumber-sumber Keunggulan Bersaing Bidang Pemasaran

\begin{tabular}{|r|l|c|c|}
\hline No & \multicolumn{1}{|c|}{ Prioritas Keunggulan Bersaing Bidang Pemasaran } & $\begin{array}{c}\text { Tingkat } \\
\text { Pentingnya }\end{array}$ & $\begin{array}{c}\text { Peringkat } \\
\text { (Rank) }\end{array}$ \\
\hline 1. & Citra merek (brand image) & 6,8056 & 1 \\
\hline 2. & Promosi periklanan & 5,3333 & 10 \\
\hline 3. & Identifikasi pasar sasaran & 6,2222 & 4 \\
\hline 4. & Kemampuan memenuhi tuntutan pasar sasaran (target market) & 6,3056 & 3 \\
\hline 5. & Penetapan harga & 4,7500 & 12 \\
\hline 6. & Pelayanan pelanggan sebelum dan setelah penjualan & 5,3889 & 8 \\
\hline 7. & Luasnya lini produk & 5,4722 & 5 \\
\hline 8. & Luasnya cakupan distribusi & 5,4444 & 7 \\
\hline 9. & Distribusi biaya rendah & 5,2222 & 11 \\
\hline 10. & Distribusi selektif & 5,3611 & 9 \\
\hline 11. & Penguasaan penjualan secara personal & 5,4444 & 6 \\
\hline 12. & Reputasi perusahaan & 6,6667 & 2 \\
\hline
\end{tabular}

\section{c. Kinerja (Performance) Sumber-Sumber Keunggulan Bersaing Bidang Pemasaran}

Rerata dan peringkat kinerja (performance) faktor-faktor keunggulan bersaing bidang pemasaran ditunjukkan dalam tabel 4 . Dari tabel 4 kita dapat melihat bahwa kinerja perusahaan manufaktur di Indonesia (yang diwakili oleh pendapat responden) cukup baik terutama dalam hal citra merek, reputasi perusahaan, identifikasi pasar sasaran dan promosi atau periklanan. Namun dalam hal biaya distribusi, kinerjanya menunjukkan rata-rata yang agak kurang memuaskan (dibawah kriteria agak baik).

Jika tabel 3 dan 4 dikaitkan kita dapat melihat bahwa sumber keunggulan bersaing yang dianggap penting ternyata juga memiliki kinerja yang lebih baik. Logikanya memang apa yang dianggap penting akan lebih diperhatikan. Jadi segala upaya akan difokuskan pada peningkatan sumber keunggulan bersaing yang dianggap lebih penting. Oleh karena itu wajar jika kinerjanyapun akan lebih baik. Sebaliknya sumber keunggulan bersaing yang dianggap kurang penting ternyata juga memiliki kinerja yang lebih jelek. Hal ini dapat dilihat pada penetapan harga dan biaya distribusi, karena peringkat pentingnya dianggap kurang (menempati urutan terbawah) maka peringkat kinerjanyapun berada pada urutan terbawah. 
Tabel 4.

Rerata dan Peringkat Skor Kinerja (Performance) Sumber-sumber Keunggulan Bersaing Bidang Pemasaran

\begin{tabular}{|r|l|c|c|}
\hline No & \multicolumn{1}{|c|}{ Prioritas Keunggulan Bersaing Bidang Pemasaran } & Kinerja & $\begin{array}{c}\text { Peringkat } \\
\text { (Rank) }\end{array}$ \\
\hline 1. & Citra merek (brand image) & 6,5278 & 1 \\
\hline 2. & Promosi periklanan & 5,5000 & 4 \\
\hline 3. & Identifikasi pasar sasaran & 5,6111 & 3 \\
\hline 4. & Kemampuan memenuhi tuntutan pasar sasaran (target market) & 5,4167 & 7 \\
\hline 5. & Penetapan harga & 5,0833 & 11 \\
\hline 6. & Pelayanan pelanggan sebelum dan setelah penjualan & 5,1667 & 10 \\
\hline 7. & Luasnya lini produk & 5,2500 & 9 \\
\hline 8. & Luasnya cakupan distribusi & 5,4167 & 6 \\
\hline 9. & Distribusi biaya rendah & 4,8611 & 12 \\
\hline 10. & Distribusi selektif & 5,3889 & - \\
\hline 11. & Penguasaan penjualan secara personal & 5,4167 & 5 \\
\hline 12. & Reputasi perusahaan & 6,4167 & 2 \\
\hline
\end{tabular}

\section{d. Rerata dan Standar Deviasi Hasil Kinerja}

Dari tabel 5 dibawah ini kita dapat melihat bahwa hasil kinerja industri manufaktur di Indonesia (yang diwakili oleh ukuran pangsa pasar dan pertumbuhan pangsa pasar) cukup baik, terutama dalam hal pangsa pasar yang menunjukkan rata-rata lebih dari kriteria baik (skala 5 berarti agak baik dan 6 berarti baik).

Tabel 5.

Rerata dan Standar Deviasi Variabel Hasil Kinerja

\begin{tabular}{|c|l|c|c|}
\hline No & \multicolumn{1}{|c|}{ Variabel Penelitian } & Rerata & Standar Deviasi \\
\hline 1. & Market Share & 6,0833 & 0,5492 \\
\hline 2. & Market Share Growth & 5,6111 & 0,6036 \\
\hline
\end{tabular}

\section{Pengujian Pengaruh Sumber-Sumber Keunggulan Bersaing Bidang Pemasaran terhadap Kinerja Perusahaan}

Untuk menguji pengaruh sumber-sumber keunggulan bidang pemasaran terhadap kinerja perusahaan, dalam penelitian ini digunakan model regresi. Model ini digunakan untuk mengetahui apakah pengaruh kompetensi pemasaran terhadap hasil-hasil kinerja (performance outcomes) industri manufaktur di Indonesia cukup signifikan. Hasil pengujian pengaruh 
sumber-sumber keunggulan bersaing bidang pemasaran terhadap kinerja perusahaan disajikan dalam tabel 6 .

Tabel 6.

Hasil Regresi Dengan Market Share Sebagai Variabel Terikat

\begin{tabular}{|c|c|c|c|c|}
\hline Variabel & $\begin{array}{c}\text { Koefisien } \\
(\boldsymbol{\beta})\end{array}$ & Std. Error & $\mathbf{T}$ & Sig. \\
\hline Konstanta & 4,390 & 0,609 & 7,204 & 0,000 \\
\hline MCOMP & 0,006993 & 0,002 & 2,811 & 0,008 \\
\hline \multicolumn{4}{|c|}{$\mathrm{R}^{2}: 0,189$} \\
\hline
\end{tabular}

Dari tabel 6 kita dapat melihat bahwa hasil regresi antara kompetensi bidang pemasaran (sebagai sumber keunggulan bersaing) dengan pangsa pasar signifikan pada $p \leq 0,05$. Hal ini berarti kompetensi bidang pemasaran berpengaruh secara positif (karena tanda pada $\beta$ variabel kompetensi bidang pemasaran positif) terhadap pangsa pasar. Dengan kata lain, pangsa pasar dapat ditingkatkan melalui upaya perbaikan kompetensi bidang pemasaran. Strategi dan taktik pemasaran sangat penting dalam upaya mencapai pangsa pasar yang ditargetkan perusahaan. Variabel bebas (kompetensi pemasaran) mampu menjelaskan 18,9\% (R2: 0,189) dari variasi variabel terikat dalam hal ini market share (pangsa pasar).

Tabel 7.

Hasil Regresi Dengan Market Share Growth Sebagai Variabel Terikat

\begin{tabular}{|c|c|c|c|c|}
\hline Variabel & $\begin{array}{c}\text { Koefisien } \\
(\boldsymbol{\beta})\end{array}$ & Std. Error & $\mathbf{t}$ & Sig. \\
\hline Konstanta & 4,299 & 0,572 & 7,517 & 0,000 \\
\hline MCOMP & 0,005415 & 0,002 & 2,321 & 0,026 \\
\hline \multicolumn{5}{|c|}{$\mathrm{R}^{2}: 0,137$} \\
\hline
\end{tabular}

Sementara dari tabel 7 kita dapat melihat bahwa hasil regresi antara kompetensi bidang pemasaran (sebagai sumber keunggulan bersaing) dengan pertumbuhan pangsa pasar signifikan pada $p \leq 0,05$. Hal ini berarti kompetensi bidang pemasaran berpengaruh secara positif (karena tanda pada $\beta$ variabel kompetensi bidang pemasaran positif) terhadap pertumbuhan pangsa pasar. Dengan kata lain, pertumbuhan pangsa pasar juga dapat ditingkatkan melalui upaya perbaikan kompetensi bidang pemasaran. Strategi dan taktik pemasaranpun sangat mutlak diperlukan 
dalam upaya mencapai pertumbuhan pangsa pasar yang ditargetkan perusahaan. Variabel bebas (kompetensi pemasaran) mampu menjelaskan $13,7 \%\left(R^{2}: 0,137\right)$ dari variasi variabel terikat dalam hal ini market share growth (pertumbuhan pangsa pasar).

\section{Pembahasan}

Hasil analisis penelitian ini menunjukkan bahwa kompetensi pemasaran mempunyai pengaruh positif terhadap hasil-hasil kinerja perusahaan. Ini berarti perusahaan dapat meningkatkan kinerja melalui usaha meningkatkan kompetensi bidang pemasarannya.

Usaha meningkatkan kompetensi pemasaran dapat dilakukan dengan memperbaiki kinerja faktor-faktor keungulan bersaing, terutama yang menjadi tanggung jawab utama bidang pemasaran. Dalam penelitian ini beberapa sumber keunggulan bersaing bidang pemasaran yang diakui oleh responden menjadi tanggung jawab utama fungsi pemasaran adalah sebagai berikut (dilihat dari besarnya persentase tanggung jawab): bagaimana menciptakan reputasi perusahaan dan membangun citra merek (brand image) yang baik, mengidentifikasi pasar sasaran secara tepat dan mampu memenuhi tuntutan pasar sasaran, melakukan promosi periklanan, memperluas cakupan distribusi serta melakukan distribusi selektif. Pelayanan sebelum dan setelah penjualan, penetapan harga dan biaya distribusi menjadi tanggung jawab fungsi pemasaran kurang dari $50 \%$. Dengan kata lain, sumber keunggulan ini menjadi tanggung jawab fungsi-fungsi lain yang ada dalam perusahaan lebih dari $50 \%$. Meskipun tanggung jawab fungsi pemasaran kurang dari $50 \%$ terhadap pelayanan sebelum dan sesudah penjualan, penetapan harga serta biaya distribusi, fungsi pemasaran tetap harus bertanggung jawab terhadap perbaikan sumber-sumber keunggulan bersaing ini.

Reputasi perusahaan merupakan faktor yang sangat penting karena hal ini menyangkut tingkat kepercayaan masyarakat atau konsumen terhadap perusahaan tersebut sehingga secara langsung mempengaruhi produk yang dihasilkan. Apabila sebuah produk dihasilkan oleh perusahaan yang mempunyai reputasi yang baik maka produk tersebut akan mendapatkan konsumen yang lebih banyak dibanding produk yang dihasilkan oleh perusahaan yang reputasinya kurang baik. Menurut beberapa pakar manajemen, reputasi perusahaan yang baik ini pada gilirannya diharapkan dapat meningkatkan profitabilitas perusahaan yang salah satunya bisa melalui perluasan pangsa pasar.

Citra merek (brand image) yang baik dapat dibangun dengan memberikan nama (brand naming) terhadap suatu produk yang mampu membangkitkan rasa percaya dan yakin terhadap kualitas produk (bisa berkaitan dengan kehandalan, kekuatan, kecepatan, status, dII). Selain itu 
kemasan yang menarik juga mempengaruhi citra merek, karena nama/merek dan kemasan secara bersama-sama akan mengkomunikasikan dan memposisikan sebuah citra merek (the brand image).

Hasil penelitian yang menunjukkan adanya pengaruh positif kometensi pemasaran terhadap pangsa pasar dan pertumbuhannya ini berarti pula bahwa strategi dan taktik pemasaran sangat mutlak diperlukan dalam upaya mencapai pangsa pasar/pertumbuhan pangsa pasar yang ditargetkan perusahaan. Strategi pemasaran dapat dimulai dengan proses segmentasi pasar secara tepat, baik berdasarkan faktor geografis, demografis, psikologis maupun perilaku konsumen. Selanjutnya perusahaan harus mengidentifikasikan segmen pasar mana yang akan dijadikan target sasaran. Target segmen pasar yang dipilih tentunya segmen yang mempunyai daya tarik tinggi, seperti mempunyai ukuran dan pertumbuhan segmen tinggi, tingkat profitabilitas tinggi, persaingan belum begitu ketat dan sebagainya. Pemilihan target segmen harus kembali mempertimbangkan sumber daya, kemampuan dan tujuan yang dimiliki oleh perusahaan. Karena kemampuan memenuhi tuntutan segmen pasar sasaran akan sangat tergantung pada sumber daya dan kemampuan perusahaan juga.

Pada sisi lain perusahaan harus dapat mengidentifikasi produk yang menjadi tuntutan pasar. Hal ini bisa dilakukan dengan proses riset pasar untuk mengetahui apa yang dibutuhkan dan diinginkan oleh pasar, bagaimana perubahan selera mereka, bagaimana mereka membuat keputusan pembelian, siapa dan apa saja yang mempengaruhi dan sebagainya. Dengan riset ini, perusahaan diharapkan dapat menyusun taktik bauran pemasaran yang tepat. Desain produk dapat dibuat sesuai selera pasar, dengan harga yang bersaing, dan mudah dijangkau oleh konsumen. Informasi (produk, harga dan tempat) ini harus dikomunikasikan pada pasar agar mereka mengetahui bahwa perusahaan mempunyai sesuatu yang dapat memuaskan mereka. Sesuatu yang dimaksud bisa berkaitan dengan luasnya lini produk, luasnya cakupan distribusi, pelayanan pelanggan sebelum dan sesudah penjualan dan sebagainya.

Untuk melakukan penyampaian informasi tersebut maka perlu dilakukan promosi karena promosi melaksanakan fungsi-fungsi penting komunikasi dengan konsumen. Promosi juga berperan dalam mempengaruhi perilaku konsumen untuk mengkonsumsi produk atau melakukan pembelian. Selain itu penyampaian informasi juga memerlukan keahlian penguasaan penjualan secara personal. 


\section{PENUTUP}

\section{Kesimpulan}

Hasil penelitian ini menunjukkan adanya hubungan positif antara kompetensi bidang pemasaran dengan ukuran hasil kenerja (pangsa pasar dan pertumbuhan pangsa pasar). Hal ini berarti meningkatnya kompetensi akan meningkatkan kinerja perusahaan dan perusahaan dengan kompetensi tinggi akan mencapai hasil-hasil kinerja yang lebih baik dibanding perusahaan yang tidak kompeten. Temuan ini konsisten dengan hasil penelitianpenelitian sebelumnya yang telah membuktikan hubungan positif kompetensi pemasaran terhadap hasil-hasil kinerja perusahaan.

Penelitian ini juga menemukan bahwa jika dilihat dari tingkat pentingnya sumber keunggulan bersaing, citra merek dan reputasi perusahaan dianggap sebagai sumber keunggulan bersaing yang paling penting. Dengan demikian kita dapat mengambil kesimpulan bahwa sumber-sumber keunggulan bidang pemasaran yang dianggap paling penting ternyata memang menjadi tanggung jawab utama fungsi pemasaran (persentase tanggung jawabnya besar).

Temuan menarik lain dari penelitian ini adalah, bahwa sumbersumber keunggulan bersaing bidang pemasaran yang dianggap lebih penting ternyata cenderung mempunyai kinerja yang lebih baik. Sehingga mungkin segala upaya akan difokuskan pada peningkatan sumber keunggulan bersaing yang dianggap lebih penting. Oleh karena itu wajar jika kinerjanyapun akan lebih baik. Sebaliknya sumber keunggulan bersaing yang dianggap kurang penting ternyata juga memiliki kinerja yang lebih jelek. Hal ini dapat dilihat biaya distribusi, karena peringkat pentingnya dianggap kurang (menempati urutan terbawah) maka peringkat kinerjanyapun berada pada urutan terbawah.

Hasil regresi antara kompetensi bidang pemasaran (sebagai sumber keunggulan bersaing) dengan pangsa pasar signifikan pada $p \leq 0,05$ dengan beta positif. Dengan demikian pangsa pasar dapat ditingkatkan melalui upaya perbaikan kompetensi bidang pemasaran. Hasil regresi antara kompetensi bidang pemasaran (sebagai sumber keunggulan bersaing) dengan pertumbuhan pangsa pasarpun ternyata juga signifikan pada $p \leq 0,05$ (tanda beta juga positif). Hal ini berarti kompetensi bidang pemasaran berpengaruh secara positif terhadap pertumbuhan pangsa pasar. Dengan kata lain, pertumbuhan pangsa pasar juga dapat ditingkatkan melalui upaya perbaikan kompetensi bidang pemasaran.

\section{Keterbatasan}

Sampel yang digunakan dalam penelitian ini adalah industri manufaktur yang sahamnya terdaftar di Bursa Efek Jakarta (BEJ) selama 
tahun 2000. Hal ini mengurangi kemampuan generalisasi hasil penelitian, artinya penelitian kemungkinan akan berbeda jika diterapkan pada perusahaan dengan sampel berbeda misalnya perusahaan manufaktur berukuran sedang atau perusahaan domestik yang sahamnya tidak terdaftar di Bursa Efek Jakarta (BEJ). Penelitian yang prosedur penarikan sampelnya bisa lebih mewakili populasi diharapkan dapat memperbaiki generalisasi hasil penelitian semacam ini.

Responden yang dipilih untuk mengisi kuesioner adalah para manajer pemasaran. Persepsi mereka dalam menjawab pertanyaan (baik yang berkaitan dengan penilaian tingkat kepentingan dan kinerja masingmasing sumber keunggulan bersaing maupun persentase tanggung jawabnya) mungkin akan berbeda jika respondennya adalah pimpinan perusahaan atau direktur perusahaan. Penelitian yang meminta pendapat pada pihak-pihak yang terkait dengan sumber keunggulan bersaing, terutama bidang pemasaran (mungkin melibatkan pimpinan perusahaan atau manajer fungsional yang lain) akan dapat memperbaiki kelemahan ini. Demikian juga metode kontak dengan responden yang melalui surat juga memiliki kelemahan seperti sudah dikemukakan sebelumnya.

Pertanyaan- pertanyaan dalam instrumen yang digunakan dalam penelitian ini semuanya bersifat positif (favorable). Pertanyaan semacam ini sangat memungkinkan responden menjawab dengan pilihan skor tinggi pada setiap pernyataan. Bahkan pada pertanyaan hasil kinerja, pengukurannya dilakukan secara subyektif. Hal ini juga memungkinkan responden menilai hasil kinerja perusahaannya cenderung diatas hasil kinerja pesaing. Penelitian berikutnya diharapkan dapat memperbaiki kelemahan dari instrumen ini.

\section{Saran}

Dengan mengingat keterbatasan-keterbatasam penelitian ini, diharapkan temuan penelitian ini tetap berguna bagi pihak industri manufaktur di Indonesia maupun bagi pihak akademisi. Kompetensi pemasaran dapat dijadikan sebagai sumber keunggulan bersaing yang dapat meningkatkan hasil kinerja perusahaan. Dengan demikian perusahaan dapat terus menggali dan mengembangkan kompetensi bidang pemasaran untuk bertahan hidup dalam era persaingan yang semakin ketat ini. Sumbersumber keunggulan bersaing yang dianggap kurang penting dapat dipertimbangkan kembali. Karena tingkat kepentingan sumber keunggulan ini ternyata juga mempengaruhi baik buruknya kinerja. Sebagai contoh, dari hasil penelitian ini sumber keunggulan yang berkaitan dengan distribusi, harga, pelayanan sebelum dan sesudah penjualan menempati urutan terbawah (dianggap kurang penting). Sebagai akibatnya kinerja sumber-sumner keunggulan tersebutpun kurang bagus dibanding sumber-sumber keunggulan yang lain. 
Distribusi berkaitan dengan upaya untuk memudahkan konsumen menjangkau produk yang mereka butuhkan dan inginkan. Cakupan distribusi yang luas penting, tapi harus dipertimbangkan masalah biayanya. Karena biaya distribusi ini akan sangat berpengaruh pada keputusan harga. Untuk kondisi pasar di Indonesia, terutama saat ini, masalah harga masih termasuk sangat peka. Mereka masih sangat terpengaruh oleh harga yang ditawarkan pesaing dalam membuat keputusan pembelian.

Pelayanan sebelum dan sesudah penjualan merupakan tuntutan pasar yang akan membuat mereka puas. Perasaan puas ini merupakan elemen penting agar konsumen menjadi pembeli setia dan merupakan promosi gratis tapi ampuh bagi perusahaan. Pelayanan sebelum penjualan dapat dilakukan dengan mengijinkan konsumen mencoba produk sebelum dibeli (mencicipi makanan, mengepas baju, mencoba mobil, melihat kondisi rumah, menduduki kursi yang mau dibeli dan sebagainya), memberikan penjelasan tentang cara penggunaan atau perawatan, memberikan informasi tentang kelebihan produk dibanding pesaing atau kemudahan pembelian dengan kredit dan sebagainya. Pelayanan setelah penjualan bisa berupa jasa pengantaran barang sampai kerumah, jasa pemasangan, garansi produk bila rusak dan sebagainya.

Dukungan fungsi-fungsi lain yang ada dalam perusahaan sangat diperlukan untuk memperbaiki sumber-sumber keunggulan tersebut. Fungsi produksi operasional, keuangan dan sumber daya manusia dituntut juga tanggung jawabnya terhadap sumber-sumber keunggulan yang nampaknya hanya menjadi tugas fungsi pemasaran ini.

Bagi para akademisi, hasil penelitian ini diharapkan dapat menjadi masukan untuk pengembangan literatur manajemen pemasaran. Disamping itu, hasil penelitian ini diharapkan dapat mendorong adanya penelitian manajemen pemasaran dan manajemen strategik lebih lanjut dengan perbaikan keterbatasan dari penelitian ini.

\section{DAFTAR PUSTAKA}

Cravens, D.W., Pemasaran Strategis, Alih Bahasa: Lina Salim,Edisi Keempat, Jilid Satu, Penerbit Erlangga, Jakarta, 1996.

Dajan, A., Pengantar Metode Statistik, Jilid Dua, LP3ES, Jakarta, 1986.

Dess, G.G., \& Davis, P.S., Porter's Generic Strategic as Determinant of Strategic Group Membership and Organizational Performance, Academy Management Journal, 27: 467-488, 1984.

Ellitan, L., Pengaruh Sumber-sumber Keunggulan Kompetitif terhadap Hasil-hasil Kinerja Industri Manufaktur di Indonesia, Tesis (tidak diterbitkan), Program Pasca Sarjana UGM, Yogyakarta, 1998. 
Handoko, T.H., Manajemen, Edisi Dua, BPFE, Yogyakarta, 1995.

Heene, A. \& Sanchez, R., Competence Based Strategic Management, John Willey \& Sons, New York, 1997.

Kotler, P., Manajemen Pemasaran: Analisis, Perencanaan, Implementasi dan Pengendalian, Penerbit Erlangga, Jakarta, 1997.

Kotler, P., Marketing Management, The Millenium Edition, Prentice Hall International, Inc., Mexico, 2000.

Nasir, M., Metode Penelitian, Ghalia Indonesia, Jakarta, 1988.

Nitisemito, A.S., Manajemen Pemasaran: Analisis, Perencanaan, Implementasi dan Pengendalian, Penerbit Erlangga, Jakarta, 1992.

Pawitra, T., Kelemahan Praktek Manajemen Pemasaran di Indonesia, Majalah Manajemen, no. 113, 1993.

Porter, M.E., Keunggulan Bersaing, Tim Penerjemah Binarupa Aksara, Binarupa Aksara, Jakarta, 1994.

Prahalad, C.K., et.al, A Strategy to Growth: The Role or The Core Competence in the Coorperation, The Portable MBA in Strategy, p. 248-269, 1994.

Rue, L.W. \& Byars, L.L, Management, Skill \& Aplication, Mc. Graw Hill Companies, 1997.

Siagian, S.P., Manajemen Stratejik, Bumi Aksara, Jakarta, 1995.

Szymansky, D.M., Badrawaj, S.G. \& Varadarajan, P.R., An Analysis of the Market Share, Profitability Relationship, Journal of Marketing, vol. 57 (July): p. 1-18, 1993.

Tambunan, T., Kinerja Ekspor Industri Manufaktur Indonesia, KADIN, Jakarta, 2001.

Tjiptono, F., Strategi Pemasaran, Edisi Dua, Penerbit Andi, Yogyakarta, 1997.

Vickery, K.S., Drodge, C. \& Markland, R.E., Source and Outcome of Competitive Advantage: An Explolatory Study in Furniture Industry, Decission Science,_25 (5): p.699-689, 1994. 